\title{
Correlation between concentrations of heavy metals in children's scalp hair and the environment. A case study from Kifissos River in Attica, Greece.
}

\author{
Evrenoglou L. ${ }^{1,}{ }^{*}$, Partsinevelou A.S. ${ }^{2,{ }^{*}}$ and Nicolopoulou-Stamati P. ${ }^{3}$ \\ ${ }^{1}$ National School of Public Health, Alexandras Av. 196, 11521, Athens, Greece. \\ ${ }^{2}$ Faculty of Geology and Geoenvironment, Department of Dynamic, Tectonic and Applied Geology, Panepistimiopolis Zografou, Athens, \\ Greece \\ ${ }^{3}$ Emeritus Professor, Department of Pathology, Medical School, National and Kapodistrian University of Athens, Greece. \\ Received: 15/05/2017, Accepted: 04/09/2017, Available online: 21/11/2017 \\ *to whom all correspondence should be addressed: e-mail: partsi@hol.gr; spartsi@geol.uoa.gr
}

\section{Key Points:}

- The heavy metal concentrations in hair reflect both the exposure and the absorbed dose. This characteristic, if interpreted properly, is useful in the assessment of exposure in the domestic and occupational environments.

- The chemical composition of PM at the Attica basin has a seasonal and a spatial variation and a great percentage of metals fall through the rain at the place of their production. In rain samples, metals like $\mathrm{As}, \mathrm{Cd}, \mathrm{Ni}, \mathrm{Cr}, \mathrm{and} \mathrm{Pb}$ were found, having common sources such as vehicle emissions/oil combustion, re-suspended road dust and industrial activity.

- Geographical analysis with G.I.S. and in-situ research in the study area confirms the plethora of industrial activities in the municipality of Kifisia, in contrast with the municipality of Kryoneri.

- All trace metals concentrations were observed in children's hair, river water and air in the areas of Kifisia and Kryoneri in Athens, Greece. Lowest heavy metals concentrations in children's hair and river water were observed in the municipality of Kryoneri, in contrast with Kifisia, which suggest that the river is contaminated locally by anthropogenic activities near and along the river banks. These results may confirm the fact that people living in the area of Kifisia (particularly its northern part near the banks of the Kifissos River) are exposed to major environmental pollution, due mainly to the human activities (traffic exhaust and industrial emissions).

\begin{abstract}
In recent years children's head hair is a biomarker frequently used for monitoring environmental exposure to heavy metals. Blood, plasma, urine and other tissues analysis were the most popular approaches to evaluate the concentrations of trace elements in human body. However, hair sample is easily collected, stored and readily analyzed. As (arsenic), Cd (cadmium), $\mathrm{Hg}$ (mercury), $\mathrm{Ni}$ (nickel) and $\mathrm{Pb}$ (lead) poses a potential threat to humans. The aim of the study is to link the concentrations of heavy metals in children's scalp hair with the environmental pollution by presenting an overview of the measurements that have been done in 12-year-old children's scalp hair living at the municipalities of Kifisia and Kryoneri, in relation with trace metals concentrations in the river water, air and tree leaves at the north zone of Kifissos River in Athens, Greece.
\end{abstract}

\section{Introduction}

Ten out of twenty trace elements are considered to be toxic for the human body. Of these, five metals, As [arsenic], Cd [cadmium], $\mathrm{Hg}$ [mercury], $\mathrm{Ni}$ [nickel] and $\mathrm{Pb}$ [lead] are dangerous to humans, with high toxicity when bounded to short chains of carbon atoms. Biochemically, the toxicity in human body begins where cations bounded with the sulfhydryl groups [-SH] of enzymes who control the speed of critical metabolic reactions (Baird \& Cann, 2005).

Toxic heavy metals such as lead, mercury and cadmium are emitted mainly from different human activities such as industrial activities [e.g. batteries, plastics, paint, burning fossil fuels] and transport. Industrial metallurgical processes produce the largest emissions of nickel.

Natural emissions of lead include soil dust, sea spray, volcanoes and forest fires. Major anthropogenic emissions are from combustion of fossil fuels, waste disposal and non-ferrous metals, iron, steel, and cement productions. The major concentrations of lead were emitted from exhaust gases vehicles using leaded gasoline, and the effective of the replacement with unleaded is clearly observed (Franzaring et al., 2010). However, lead production, mainly such as suspended particles, still remains in the environment (Bacon, 2002).

It is well known that $\mathrm{Pb}$ affects several enzymatic processes responsible for heme synthesis, the developing nervous system, the cardiovascular and endocrinology system and kidney. Low lead blood concentrations in 6-year children 
can cause subtle neurobehavioral dysfunction (Winneke et al., 1994), significant delays in all pubertal measures (breast and pubic hair development) among African Americans and Mexican Americans (Selevan et al., 2003), and a decline of 7.4 IQ points (Canfield et al., 2003) when average blood concentrations of lead increased from 1 to $10 \mathrm{mg} / \mathrm{L}$. Lead accumulates in the skeleton which is potentially dangerous during pregnancy. Furthermore, the toxicity of lead is proportional to the concentrations in the soft tissues but not in blood or bone.

Natural Releasing cadmium sources into the atmosphere are volcanoes, wind suspended particles and biogenic emissions. As anthropogenic sources, cadmium is specially attributed to non-ferrous metal, iron and steel production due to a wide usage of its components in current technology. Several effects are observed after cadmium exposure. The inhalation of cadmium-containing tobacco smoke is a dominant source of cadmium exposure (Jarup, 1998). Chronic high-dose effects causes Itai-itai disease, is nephrotoxic and even low burdens may produce subtle effects on the proximal tubule in children (Burbure et al., 2003). Jarup et al., 2009 reports that "no margin of safety exists between the point of departure and the exposure levels in the general population and measures should be put in place to reduce exposure to a minimum".

Mercury may occur naturally in the environment due to mineral deposits, volcanoes, forest fires, oceanic emission, and crust degassing. On global scale, the largest anthropogenic emissions of mercury in air come from the combustion of coal and other fossil fuels. Also, mercury can be released by human activities such as mineral processing, mining, chloroalkali production and combustion of fossil fuels. In the environment, $\mathrm{Hg}$ occurs in metallic or elemental, inorganic, and organic forms (ATSDR, 1999). Methylated mercury accumulates in animal tissues, including fish and can easily permeate the brain membrane. The side effects of mercury at lower exposure levels vary between individuals, with a debilitating and sometimes deadly condition of infants and children. Symptoms have been well documented in the literature, from the treatment of syphilis (Hirschhorn et al., 2001), the mercurials used in children powders causing acrodynia (or pink disease) (Dinehart et al., 1988), the mercury nitrate in hatters (O'Carroll et al., 1995), methyl mercury in fish in Japan with cerebral arteriosclerosis in infants suffering from Minamata disease (Fukuda et al., 1999; Harada, 1995), the consumption of homemade bread contaminated with a methylmercury ( $\mathrm{MeHg}$ ) fungicide in Irak (Bakir et al., 1973), until symptoms caused by occupational exposure to mercury vapor (Ramazzini, 1983) and blepharoconjunctivitis and punctate keratitis in many contact lens wearers using contact lens solutions containing ethyl mercury (Campbell et al., 1992).

Arsenic is widely distributed in the Earth's crust and is usually found in the environment combined with other elements such as oxygen, chlorine, and sulfur. Most inorganic and organic arsenic compounds are white or colorless powders that do not evaporate, with no smell and special taste. Inorganic arsenic has been recognized as a human poison since ancient times, and large oral doses [above 60 ppm in water] can result in death (ATSDR, 2007). Arsenic in air is usually mixed with arsenate. The most common symptoms after human poison are stomachache, nausea, vomiting, diarrhea, decreased production of red and white blood cells which may cause fatigue, abnormal heart rhythm, blood-vessel damage resulting in bruising, and impaired nerve function causing a "pins and needles" sensation in hands and feet. Also, patches of darkened skin and the appearance of small "corns" or "warts" on the palms, soles, and torso, are often associated with changes in the blood vessels of the skin (ATSDR, 2007). Children who are exposed to inorganic arsenic may have many of the same symptoms as adults, and long-term exposure to inorganic arsenic in children may result in lower IQ scores (Wright RO). Arsenic can cross the placenta (such as all chemicals with low molecular weight) and has been found in fetal tissues, and at low levels in breast milk. The International Agency for Research on Cancer (IARC) has determined that inorganic arsenic is carcinogenic to humans (ATSDR, 2007).

Nickel is an abundant element in Earth, and can be combined with other metals to produce stainless steel and alloys used in coins and jewelry. $\mathrm{Ni}$ is emitted by automobiles, exhaust gases and bitumen, smoking. This toxic element accumulates with age and causes cardiovascular disease, contact dermatitis and is related with lower levels of immunoglobulins. The International Agency for Research on Cancer (IARC) has determined that and some nickel compounds are carcinogenic to humans and metallic nickel may possible is (ATSDR, 2005).

Great cities worldwide with air pollution problems, usually had important concentrations of toxic heavy metals, chemical combined with particulate matter. Current air quality assessment is based on the determination of a specific size range $\left(\mathrm{PM}_{10}\right.$ or $\left.\mathrm{PM}_{2,5}\right)$ as well as in their chemical composition, in order to introduce new technologies and guidelines, mainly for health effect preventions. Health significance of particulate matter has been highlighted by many epidemiological studies (Kunzli et al., 2000; Katsouyanni et al., 2001; Pope et al., 2002). A strong correlation between high concentrations of $\mathrm{PM}_{10}$ and mortality was showed by Dockery and Pope, as an acute inflammatory reaction and DNA damage of pulmonary epithelial cells (Dick et al., 2003). Also, several studies on the chemical composition of particulate matter in metals have been reported

Athens is one of the greater coastal urban cities in the Mediterranean region, with an incremented population from 1.4 million (1950) to 4.5 million (2010) within a basin of about $600 \mathrm{~km}^{2}$. Air pollution are generated from a very complex meteorological and topography conditions in combination with major industrial activities and heavily traffic. The worst air pollution episodes and major concentrations of particulate matter have been recorded during periods with $\mathrm{S} / \mathrm{SW}$ winds. At the dry summer suspension of surface dusts and formation of secondary particles are favored (Dall'Osto, 2006). 
Chemical composition of PM, and determination of toxic trace metals levels became the main subject of different researches at the Attica basin (Scheff and Valiozis, 1990; Torfs and van Grieken, 1997; Thomaidis et al., 2003; Manalis et al., 2005; Vassilakos et al., 2005; Vasilakos et al., 2007). Industrial wastewaters, surface runoff and air pollution of the city are the main sources of toxic heavy metals pollution of Kifissos River.

Biomonitoring with plant materials has been used in several analyses for monitoring elemental deposition from atmosphere. Trees are a widely geographic distribution and systematic sampling can provide a useful network data for air pollution assessment, reflecting the cumulative trend from soil and air pollution (Sawidis, 2011). The aim of the study is to present the relationship between the heavy metal concentrations in children's scalp hair and in the environment. The children were 12 years old living at the municipalities of Kifisia and Kryoneri and the relationship was made by comparing the trace metals concentrations found in scalp hair and the respectively concentrations in the river water, air and tree leaves at the northern zone of Kifissos River.

\section{Materials and Methods}

\subsection{The study area}

The study area concerns the north part of the Kifissos River basin (Figure 1) which is characterized by anthropogenic interventions such as intensive agricultural activities and a dense road network. The intensive urbanization and the hard action of industry (almost $70 \%$ of the total river catchment area) represent a major threat to the environment of the study area. Two schools from different municipalities of Athens were chosen, which are Kifisia and Kryoneri. Kifisia is exposed to environmental pollution, in contrast to Kryoneri, which has a lower anthropogenic influence.

In the northern zone of the Kifissos River two principal zones for the protection of the natural environment are delimited. The $A^{\prime}$ protection zone includes all the area located within $50 \mathrm{~m}$ from both sides of the river banks and streams. This area is defined as an area of environmental education, outdoor recreation and agricultural uses. Construction and alteration of the natural landscape are not allowed. The $B^{\prime}$ protection zone includes the boundaries of $A^{\prime}$ zone comprising the limitations that have been determined by coordinates. In this zone agricultural, residential, recreational and cultural uses as well as environmental education and sports are allowed. The construction of fences in the $A^{\prime}$ and $B^{\prime}$ zones is permitted just for the protection of the habitants and security reasons. Also, in both zones the disposal of rubbles, and solid and water wastes is prohibited.

Geologically, the study area features alpine and post-alpine formations. Alpine formations of mountains cover $65 \%$ of the total extent of the river's drainage area. Post-alpine formations (conglomerates, marls, sandstones and alluvial deposits) can be divided into tertiary and quaternary deposits of terrestrial and marine origin. Also, there are artificial embankments made of stone along the main course of the river for the most of its length. The mountainous and semi-mountainous parts of drainage basin mainly consist of karstified limestones, marbles and schists, while the low-land parts have been totally covered with alluvial depositions and building materials (concrete, slabs etc.). In addition, due to its karstic background, the watershed has a significant groundwater yield (Rozos et al., 2004). The geological formations of the study area are not correlated with the existence of heavy metals, as the only formations which could enrich the surface water with trace metals are the ophiolitic and metamorphic rocks (Kelepertzis, 2007). The training and the diversion of the rivers Kyklovoros, Profitis Daniil and partially of Ilissos River to Kifissos is one of the most important projects for sewerage and flood protection of Athens. Nevertheless, the surface elevation difference between upland and lowland areas still remain a serious problem for extensive flooding (Evelpidou et al., 2009). The last forest fire which was located near the study area was at 2009 and due to lack of data, correlation between the fires and heavy metal concentrations cannot be done.

\subsection{Geographical Analysis}

To register human activities in the study area a Global Positioning System device (Garmin GPS e Trex 10) was used and obtained data (coordinates) were registered and stored in a geographic database (Geographic Information System, GIS). Additionally, data on the river basin, the river network, the geology and the protected areas were digitized and stored in a G.I.S. database. This resulted in different layers of data. The recorded information is mapped. The maps provide an overview of the region's environmental situation.

\subsection{Hair sample collection and analysis}

Hair samples were collected in two (2) primary schools. Twenty-one (21) samples were collected in the school of the municipality of Kifisia ( 8 boys and 13 girls) and 18 samples from the school of the Kryoneri Municipality ( 8 boys and 11 girls). The Ministry of Education, Lifelong Learning and Religious Affairs provided written permission for the research as well as the parents of the children, after being informed about the objectives of the study. In parallel, parents were invited to answer a questionnaire which was designed to obtain certain information about children's food habits, general health condition, smoking habits of parents and medication. The study was also approved by the Bioethical Commission of the Medical School of Athens.

To enhance the environmental relevance of the samples, hair used in the analysis has not been subjected to chemical treatment that could disturb the structure of the keratin sheath and it was ensured that the children are residing permanently in the study area. Samples were collected near the scalp (the first $2-5 \mathrm{~cm}$ of recent growth was used) in order to reduce the contribution of exogenous contamination, with stainless steel scissors and placed in wide closed sterile polythene containers, in order to be transferred to the laboratory to conduct the chemical analysis. 


\subsection{Water samples}

Water samples were collected from three different stations, near the primary schools, at the municipalities of Philadelphia, Kifisia and Kryoneri. In every station, 5 Kifissos River's water samples were collected (15 samples in total). A Global Positioning System device (Garmin GPS e Trex 10) was used in order to register the sampling stations. The data were stored in a geographic database (Geographic Information System, GIS). The samples were collected according to the guidelines of the Standard Methods for the Examination Water and Wastewater and was stocked in polyethylene bottles, in order to be transferred in the laboratory to determine the concentration of heavy metals.

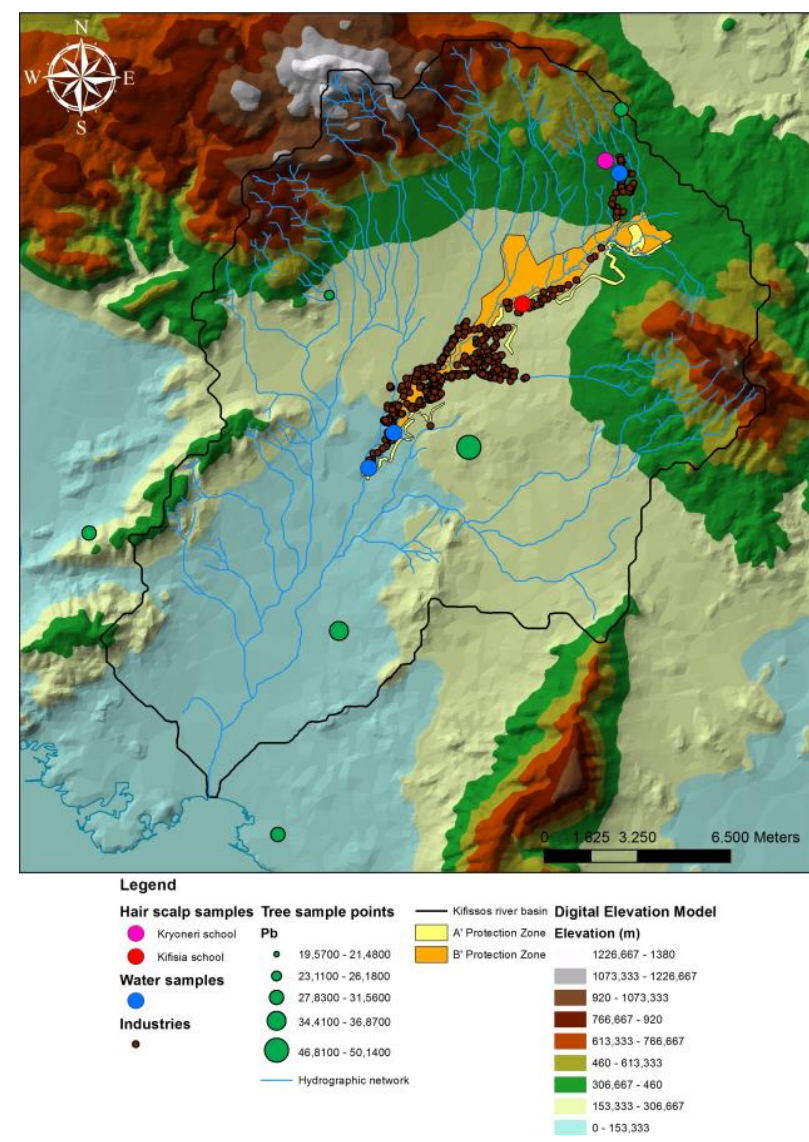

Figure 1. Basic characteristics and sampling in the study area

\section{Hair as a bioindicator for exposure to trace metals}

The health-related monitoring component of the global environmental monitoring system (GEMS) aims to assess human exposure to pollutants. GEMS recommends that international studies monitor selected metals in human tissues (Vahter, 1982).

Hair obtained from the head has become an ideal indicator for exposure to environmental heavy metals (Barlow et al., 1995; Wilhelm et al., 1994) as hair has been described as a "minor excretory organ" for trace metals, therefore it would seem reasonable to relate hair metal levels with the amount of element ingested and individual's metabolism.
Hair is a major route of excretion of chemicals having a high affinity for trace elements. It is believed that, as the keratin which comprises human hair consists of about $14 \%$ of the amino acid cystine, the metals found in hair are bound to sulphur atoms in cystine and to sulphydryl (-SH) groups present in other amino acids to form mercaptides or metalloproteins (Katz, 1988). Also, metals ions have a high affinity with the melanin incorporated into the hair and the ionic binding may also be enhanced by forces such as van der Waal's attraction (Srogi, 2006).

Thus, metals may be absorbed and bound in hair by different pathways. Endogenously, from circulating blood metals during hair formation in the hair follicles (Clarkson, 1983), semiexogenously by the absorption of metals who are excreted by sebaceous and sweat glands, and finally exogenously by the contact of hair with contaminated ambient air, soil and dust, and cosmetics such as shampoo (Herber et al., 1983). Metals that are not bound chemically with hair may be removed using different washing procedures.

There are different theories for the uptake of chemical substances into hair, and all accept that chemical substances or their metabolites are transported to the hair root by the bloodstream and are then incorporated into matrix cells and melanocytes during the keratinization process. The extent to which substances are incorporated in hair not only depends on the concentration, but also largely on the chemical structure and pharmacokinetics of the substance (Birngruber, 2012).

Hair analyses have thus become an important approach to understanding quantitative changes in certain trace elements inside the body (Srogi, 2004; Srogi, 2006) because can store information for months and even for years. Hair has been called a "filament of record" or a "biological dosimeter" Segment of hair taken from the skin of the scalp between 0 and $10 \mathrm{~mm}$, provide information about exposure before to sampling, and cutting hair into segments, it is possible to trace the exposure history of individuals. Hair which has been colored artificially or subjected to any treatment cannot be use as a material for biomonitoring.

Hair analysis may have useful applications in investigations for trace elements in dietary habits, in screening after use of drugs (Valente et al., 1981), in exposure assessment for occupational environment (Foo et al., 1993; Taylor, 1986) and in environmental exposure from air, water and soil pollution. Blood and urine analyses are the most traditional approaches, and the fluctuation is in direct response to any change in physiological or environmental conditions (Srogi, 2006).

Biomonitoring hair analysis for monitoring metal burden has some advantages because toxic metals accumulate or bioconcentrate in hair (such as Arsenic and Mercury) and do not decrease as they do in blood and urine. Over the traditional non-invasive collection of other tissues, hairs samples are easily obtained without permission problems, without almost none post contamination risks when sampling and storage is adequate (usually in polyethylene 
containers). Hair samples do not require refrigeration and standardized methods are available for further analysis. A small amount of hair $(2-3 \mathrm{~cm})$ from the scalp can potentially represent the exposure to metals over the past 2-3 months, remaining at detectable levels (Chojnacka et al., 2012), leading to use of hair as biomonitoring for trace elements present in the environment (Schuhmacher et al., 1991; Wilhelm et al. 1994; Schuhmacher et al., 1996; Sen and Chaudhuri, 1996) or at the workplace (Ashraf et al., 1994). However, hair analysis is subject to certain limitations that concern mainly the interpretations of the results who are involved with the factors which can influence the level of trace elements in hair, as well as the attempts to differentiate between external and internal deposition (Chojnacka et al., 2012). External contaminations can deposits of sebum from polluted air residues or residues of cosmetic or pharmaceutical products. Additionally, the concentrations of most trace elements are frequently greater in hair than they are blood or urine (Rodrigues et al., 2008).

\section{Children exposure to toxic trace elements}

As urban areas are densely populated, good quality of urban environment is essential for community health (Li et al., 2001). In particular, children are more susceptible to the adverse health effects of trace elements than adults due to their small body size and developing endocrinology and nervous systems. Dust inhalation, food, water, including skin contact and even direct soil intake are the most common routes of exposure (Ljung et al., 2006). The absorbed percentage of lead by respiratory and gastrointestinal tract of children is greater than of adults (Al-Saleh et al., 1999), due to the faster inhalation rate, their higher metabolic index and the greater physical activity (Fitzgerald et al., 1998).

The pathways between the sources of these trace elements and human exposure are complex. The evaluation process is further complicated by the fact that many of them are persistent and accumulate in human tissues (Nicolopoulou et al., 2007). Thereby, with the advantages and disadvantages of hair analysis of trace elements as biological material for exposure assessment, children hair samples living at the north zone of Kifissos River was considered the first important step in health risk assessment process. At two different Attica municipalities, Kifisia (urban) and Kryoneri (suburban), north and near to the banks of the Kifissos River, values of $\mathrm{As}, \mathrm{Cd}, \mathrm{Cr}, \mathrm{Hg}, \mathrm{Ni}$ and $\mathrm{Pb}$ were determinate in children scalp hair between 11 and 12 years of age $(\mathrm{AsH}, \mathrm{CdH}, \mathrm{CrH}, \mathrm{HgH}, \mathrm{NiH}$ and $\mathrm{PbH})$ living in the study areas as well as in river water samples (AsW, CdW, CrW, HgW, NiW and PbW). Also, some additional heavy metals measurements for water samples from Kifissos River were done. Human activities at the study area were registered using a geographic database (Geographic Information System, GIS).

The combinations of low precipitations from spring to autumn, trace metals concentrations and photochemical formation of smog, represents an often characteristic of Athens air quality (Remoundaki et al., 2011). Heavy metals and Arsenic represent an important fraction of the PM atmosphere of Athens, with increased content in inhalable fraction (Farmaki and Thomaidis, 2008). In table 1 are summarized the concentrations of these elements in children scalp hair, in Kifissos River at the municipalities of Kifisia and Kryoneri, in air, and tree leaves of Attica basin.

Trace metals in air from the referenced stations were taken because they are the most representative values for the study area. Also, the estimated concentration of $\mathrm{PM}_{10}$ for Marousi and Thrakomacedones, according to 'BOND' research program (model who considers biogenic sources from forests, grasslands, agriculture shrub-lands, wetlands, animals and humans, sea and soils) was 19 and $2 \mathrm{~kg} /$ day respectively (Vasilakos, 2007).

\section{Discussions}

Inhalation is the most important route of exposure for children, because very small inhaled particles that deposit on lung epithelium bypass uptake control in the gastrointestinal tract and liver entering directly in the systemic circulation (Schroeter et al., 2011). Chronic exposure to severe urban air pollution causes a significant imbalance in genes essential for cell proliferation, apoptosis, oxidative stress, inflammation, innate and adaptive immune responses and early Alzheimer's diseaserelated pathological processes leading to neurofibrillary tangle formation start early in childhood or in early young adulthood (Calderón-Garciduenasc et al., 2012).

Hair growth and analysis studies assessed hair growth rates and the relationship with concentrations of trace metals between methylmercury intake and hair levels (Clarkson, 1983). Minamata disease sufferers were thought to have extremely high mercury levels in hair.

Diachronically, different studies have been reported the relation between children hair analysis and physical or mental disorders. De Palma et al., found in a meta-analysis study of elements contents in hair of autistic children, that there is no relation between concentrations of $\mathrm{Hg}$ and $\mathrm{Cd}$ with autism, with a week correlation only for $\mathrm{Pb}$. Significant lower concentration of $\mathrm{Hg}$ (about 8-fold less) found Holmes et al. and $\mathrm{Hu}$ et al. in the first autistic baby haircut in relation with healthy children, with significant higher concentrations in mothers of autistic children who were exposed through Rho D immunoglobulin injections and amalgam fillings than controls mothers. Also, significant high concentrations of $\mathrm{Pb}$ and $\mathrm{Hg}$ were found in hair analysis of autistic children compared with control group (Fido and Al-Saad 2005; Lakshmi Priya and Geetha, 2010). Statistically lower concentrations of $\mathrm{Ni}, \mathrm{Cd}$, and $\mathrm{Pb}$ found Yasuda et al. in hair of autistic children as well as Kern et al. found for $\mathrm{Hg}, \mathrm{Pb}, \mathrm{As}$ and $\mathrm{Cd}$.

In children with certain disorders of the osteomuscular articular system, significant higher hair concentrations of $\mathrm{Pb}, \mathrm{Zn}$ and $\mathrm{Mg}$ where found in relation with healthy group, whereas the level of Cu was lower (Lech, 2002).

In table 1, data from different studies of hair trace metals concentrations are summarized. 
The chemical composition of PM at the Attica basin has a seasonal and a spatial variation. At the Agia Paraskevi air station, summer concentrations of $\mathrm{Hg}, \mathrm{Cd}$ and $\mathrm{Ni}$ in $\mathrm{PM}_{10}$ were higher, while during winter $\mathrm{As}$ and $\mathrm{Pb}$ concentrations were higher (Vassilakos, 2005). Also in $\mathrm{PM}_{2,5}$, As presented its maximum concentration on September, $\mathrm{Hg}$ and $\mathrm{Cd}$ on October, $\mathrm{Pb}$ and $\mathrm{Ni}$ reached maximum value during August (Vassilakos, 2007).

Table 1. Comparison means trace elements concentrations in children scalp hair, Kifissos River, air and tree leaves.

\begin{tabular}{|c|c|c|c|c|c|c|c|c|}
\hline Metal & $\begin{array}{c}\text { Children } \\
\text { Hair } \\
\text { Kifisia } \\
\text { (Urban) }^{\mathrm{a}}\end{array}$ & $\begin{array}{c}\text { Children } \\
\text { Hair } \\
\text { Kryoneri } \\
\text { (Suburban) }^{\mathrm{a}} \\
\end{array}$ & $\begin{array}{l}\text { Kifissos } \\
\text { River } \\
\text { (Kifisia) }^{a}\end{array}$ & $\begin{array}{c}\text { Kifissos } \\
\text { River } \\
\text { (Kryoneri)a }^{\text {Kryon }}\end{array}$ & $\begin{array}{c}\text { Marousi } \\
\text { Air Station }^{\text {b }} \\
\text { (urban) }\end{array}$ & $\begin{array}{l}\text { Thrakomacedo } \\
\text { nes Air Station }^{\text {b }} \\
\text { (suburban) }\end{array}$ & $\begin{array}{l}\text { Aghia Paraskevi } \\
\text { Air Station' } \\
\text { (suburban) }\end{array}$ & $\begin{array}{c}\text { Tree leaves } \\
\text { at Attica } \\
\text { basin }^{d}\end{array}$ \\
\hline As & 0,035 & 0,026 & 4,518 & 1,234 & 5,6 & 4,8 & 5,78 & n.a. \\
\hline $\mathrm{Cd}$ & 0,029 & 0,025 & 0,2 & 0,038 & 2,6 & 1,9 & 0,58 & 0,62 \\
\hline $\mathrm{Hg}$ & 0,52 & 0,36 & $*$ & $*$ & * & * & 0,09 & n.a. \\
\hline $\mathrm{Ni}$ & 1,38 & 0,62 & 68,74 & 6,002 & 11,0 & 9,2 & 1,33 & 22,52 \\
\hline $\mathrm{Pb}$ & 3,31 & 0,80 & 5,94 & 0,304 & 46,6 & 25,4 & 10,4 & 29,06 \\
\hline $\mathrm{Cr}$ & 2,11 & 0,66 & 21 & 0,874 & 13,1 & 10,1 & n.a. & 14,63 \\
\hline
\end{tabular}

n.a. = not available, ${ }^{*}=$ Concentration of $\mathrm{Hg}$ was below the detection limit

(a) Evrenoglou et al., 2013; (b) Manalis et al., 2005; (c) Vasilakos et al., 2007; (d)Sawidis et al., 2012

Concentrations of trace metals in children hair are in $\mu \mathrm{g} / \mathrm{g}$, in air are in $\mathrm{ng} / \mathrm{m}^{3}$, and in tree leaves in ppm

Also, a great percentage of metals fall through the rain at the place of their production (Nurnberg et al., 1984). In rain samples from the station of Athens University Campus (AUC), during the winter period 1/10/97 -31/3/98, metals like $\mathrm{As}, \mathrm{Cd}, \mathrm{Ni}, \mathrm{Cr}$, and $\mathrm{Pb}$ were found, having common sources such as vehicle emissions/oil combustion, resuspended road dust and industrial activity (the industrial area of Thriasio basin at the west of Athens, the National Highway and the industries at the north and northeast of Athens, and central heat) (Kanellopoulou, 2001).

\section{Conclusions}

Hair growth averages 1-1.5 cm per month and, depending on the length of the hair, provides a time record of previous $\mathrm{Hg}$ exposure. Lead, cadmium, mercury, arsenic and nickel are mainly emitted from industrial activities and combustion coal. Although the atmospheric levels are low (related with the assessment threshold), they are deposited in soils, sediments, body waters and organisms, building up the bioaccumulation and biomagnifications in the food chain.

Lead and cadmium are endocrine disrupters and probably they can also induce changes in hair condition, since hormones and lipids play a very important role in the development and cyclic growth of the hair follicle.

Another important source of exposure that is related with exposure to $\mathrm{Pb}, \mathrm{Cd}$ and $\mathrm{As}$ is active or passive cigarette smoking. Their volatile compounds are absorbed by the inhalation route, transferred to blood stream and accumulate in specific organs, e.g. kidney or liver. Increased levels of these toxic elements in hair, blood and urine were reported.

Increased level of $\mathrm{Pb}$ in hair causes neurobehavioral decrements, renal impairment, which leads to development of hypertension (ATSDR, 2007). The presence of $\mathrm{Pb}$ in blood adversely affects kidney, hematopoietic system and central nervous system. Increased hypertension was reported in patients with significantly higher level of $\mathrm{Cd}$ in hair vs. control. Increased levels of $\mathrm{Ni}$ in hair are related with the level of urbanization. It was proposed that the level of $\mathrm{Ni}$ in hair could be used as marker of cardiovascular problems (ATSDR, 2005).

Usually As is absorbed by inhalation or ingestion (from polluted air or water) route. Since arsenic acts as an inhibitor of metabolic enzymes, the excessive exposure can lead to multi-system organ failure (ATSDR, 2007). Hair binds arsenic in irreversible way and become an excellent bioindicator for the determination of human exposure (Liu et al., 2011).

Reported rates of autism have increased sharply in the United States and the United Kingdom. One possible factor underlying these increases is increased exposure to mercury through thimerosal-containing vaccines, but vaccine exposures need to be evaluated in the context of cumulative exposures during gestation and early infancy (Holmes et al., 2003). Repetitive mercury exposure during pregnancy and after birth in genetically susceptible individuals is one potential pathogenetic factor in autism (Mutter et al., 2005).

The determined concentrations of arsenic, cadmium, chromium, mercury, lead and nickel in the atmosphere of Attica basin were low compared with the directive 96/62/E.U. for $\mathrm{PM}_{10}$ and until now there is not a Directive for fine particles, but the question is if there are safe thresholds for children exposure to toxic heavy metals. A complete assessment of $\mathrm{Hg}$ levels in the atmosphere is very difficult since only a small percentage of mercury in air is expected to be in the particle phase (Manalis, 2005). Trace levels from Agia Paraskevi air station (another suburban area of Attica basin) are between Marousi and Thrakomacedones, who probably due to the different meteorological conditions (such as wind velocity and direction), topography and conditions.

All trace metals concentrations at Marousi are higher than the Thrakomacedones air station, as well as all the arithmetic mean values in children hair, river water and air was higher in the area of Kifisia than the Kryoneri. Geographical analysis (G.I.S.) confirms the plethora of 
industrial activities in the municipality of Kifisia in relation with the municipality of Kryoneri, which undoubtedly pollutes the region. The observed lowest heavy metals concentrations in river water, at the municipality of Kryoneri compared with Kifisia, suggest that the river is contaminated namely by anthropogenic activities near and along the river banks. These results may confirm the fact that the area of Kifisia (particularly its northern part near the banks of the Kifissos River) is exposed to major environmental pollution, due mainly to the human activities (traffic exhaust and industrial emissions).

Clearly, more research is needed to fully define the correlation between the levels of essential trace elements in human scalp hair and exposure in the domestic and occupational environments. The heavy-metal contents of hair reflect both the exposure and the absorbed dose and, if interpreted properly, this characteristic is also useful in the assessment of exposure.

\section{References}

Al-Saleh I., Nester M., Devol E., Shinwar N. and Al-Shahria S. (1999), Determinants of blood lead levels in Saudi Arabian schoolgirls, Int. J. Occup. Environ. Health, 5, 107-114.

Ashraf W., Jaffar M. and Mohammad D. (1994), Trace metal contamination study on scalp hair of occupationally exposed workers, Bull Environ Contam Toxicol., 53, 516-523.

ATSDR (1999), Toxicological profile of Mercury. Agency for Toxic Substances and Disease Registry, Division of Toxicology, Atlanta, GA, USA.

ATSDR (2005), Toxicological profile for Nickel. Agency for Toxic Substances and Disease Registry, Division of Toxicology, Atlanta, GA, USA.

ATSDR (2007), Toxicological profile of Arsenic. Agency for Toxic Substances and Disease Registry, Division of Toxicology, Atlanta, GA, USA.

ATSDR (2007), Toxicological profile of Lead. Agency for Toxic Substances and Disease Registry, Division of Toxicology, Atlanta, GA, USA.

ATSDR (2012), Toxicological profile of Cadmium. Agency for Toxic Substances and Disease Registry, Division of Toxicology, Atlanta, GA, USA.

Bacon J.R. (2002), Isotopic characterisation of lead deposited 1989-2001 at two upland scottish locations, J Environ Monit, 4, 291-299.

Baird C. and Cann M. (2005), Environmental Chemistry, W.H. Freeman and Company, NY $3^{\text {rd }} \mathrm{Ed}$.

Bakir F., Damluji S.F., Amin-Zak L., Murtadha M., Khalidi A., AlRawi N.Y., Tikriti S., Dahahir H.I., Clarkson T.W., Smith J.C. and Doherty R.A. (1973), Methylmercury poisoning in Iraq, Science, 181, 230-240.

Barlow P.J., Sidani S.A. and Lyons M. (1995), Trace elements in hair in the UK Results and interpretation in the preconception situation, Sci Environ, 42, 121-131.

Birngruber C.G. and Verhoff M.A. (2012), The color of human hair. Handbook of hair in health and disease, 31-49.

Burbure C., Buchet J.P., Bernard A. Leroyer A., Nisse C., Haguenoer J.M., Bergamaschi E and Mutti A. (2003), Biomarkers of renal effects in children and adults with low environmental exposure to heavy metals, J Toxicol Environ Health A, 66, 783-798.
Calderón-Garcidueñas L., Serrano-Sierra A., Torres-Jardón R., Zhu H., Yuan Y., Smith D., Delgado-Chávez R., Cross J.V., MedinaCortina H., Kavanaugh M. and Guilarte T.R. (2012), The impact of environmental metals in young urbanites' brains, Exp Toxicol Pathol, doi: 10.1016/j.etp.2012.02.006.

Campbell D., Gonzales M. and Sullivan J.B. Jr. (1992), Mercury. In: Hazardous Materials Toxicology, Clinical Principles of Environmental Health (JB Sullivan Jr, GR Kreiger, eds). Baltimore, Maryland: Williams and Wilkins, 824-833.

Canfield R.L., Henderson C.R. Jr, Cory-Slechta D.A., Cox C., Jusko T.A. and Lanphear B.P. (2003), Intellectual impairment in children with blood lead concentrations below $10 \mathrm{microg} / \mathrm{dl}$, N. Engl. J. Med., 348, 1517-26.

Chojnacka K. and Mikulewicz M. (2012), Hair mineral analysis in the assessment of human exposure to metals, Handbook of hair in health and disease, 279:292.

Clarkson TW. (1983), Mercury, Annu Rev Public Health, 4, 375-380.

Dall'Osto M. and Harrison RM. (2006), Chemical characterisation of single airborne particles in Athens (Greece) by ATOFMS, Atmospheric Environment, 40, 7614-7631.

De Palma G., Catalani S., Franco A., Brighenti M. and Apostoli P. (2011), Lack of correlation between metallic elements analyzed in hair by ICP-MS and autism, J Autism Dev Disor, 42(3), 342-353.

Dick C.A.J., Brown D.M., Donaldson K. and Stone V. (2003), The role of free radicals in the toxic and inflammatory effects of four different ultrafine particle types, Inhalation Toxicology, 15, 39-52.

Dinehart S.M., Dillard R., Raimer S.S., Diven S., Cobos R. and Pupo R. (1988), Cutaneous manifestations of Acrodynia (pink disease), Arch Dermatol, 124, 107-109.

Evelpidou N., Mamassis N., Vassilopoulos A., Makropoulos C. and Koutsoyiannis D. (2009), Flooding in Athens: the Kephisos River flood event of 21-22/10/1994. International Conference on Urban Flood Management. Paris: UNESCO.

Evrenoglou L., Partsinevelou A.S., Stamatis P., Lazaris A., Patsouris E., Kotampasi C. and Nicolopoulou-Stamati P. (2013), Children exposure to trace levels of heavy metals at the north zone of Kifissos River, Science of the Total Environment, 443, 650-661.

Farmaki E.G. and Thomaidis N.S. (2008), Current status of the metal pollution of the environment of Greece - A review, Global NEST Journal, 10, 3, 366-375.

Fido A. and Al-Saad S. (2005), Toxic trace elements in the hair of children with autism, Autism, 9(3), 290-298.

Fitzgerald E.F., Schell L.M., Marshall E.G., Carpenter D.O., Suk W.A. and Zejda J.E. (1998), Environmental pollution and child health in Central and Eastern Europe, Environ. Health Perspect, 106, 307-311.

Foo S.C., Khoo N.Y., Heng A., Chua L.H., Chia S.E., Ong C.N., Ngim C.H. and Jeyaratnam J. (1993), Metals in hair as biological indices for exposure, Int Arch Occup Environ Health, 65, 383-386.

Franzaring J., Holz I., Zipperle J. and Fangmeier A. (2010), Twenty years of biological monitoring of element concentrations in permanent forest and grassland plots in Baden-Württemberg (SW Germany), Environ Sci Pollut Res Int, 17, 4-12.

Fukuda Y., Ushijima K., Kitano T., Sakamoto M. and Futatsuka M. (1999), An analysis of subjective complaints in a population living in a methylmercury-polluted area, Environ Res, 81(2), 100-107. 
Harada M. (1995), Minamata disease: methylmercury poisoning in Japan caused by environmental pollution, Crit Rev Toxicol, 25(1), 1-24.

Herber R.F.M., Wibowo A.A.E., Das H.A., Egger R.J., van Deyck W. and Zielhuis R.L. (1983), Trace element levels in hair of eightyear-old children, Int. Arch. Occup. Environ. Health, 53, 127-137.

Hirschhorn N., Feldman R.G. and Greaves I.A. (2001), Abraham Lincoln's blue pills, Perspect Biol Med, 44(3), 315-332.

Holmes A.S., Blaxill M.F. and Haley B.E. (2003), Reduced levels of mercury in first baby haircuts of autistic children, Int J Toxicol, 22(4), 277-285.

Jarup L. and Akesson A. (2009), Current status of cadmium as an environmental health problem, Toxicol Appl Pharmacol, 238, 201-208.

Jarup L., Berglund M., Elinder C.G., Nordberg G. and Vahter M. (1998), Health effects of cadmium exposure-a review of the literature and a risk estimate, Scand J Work Environ Health, 24, Suppl 1:1-51.

Kanellopoulou E.A. (2001), Determination of heavy metals in wet deposition of Athens, Global NEST: the Int. J., 3(1), 45-50.

Katsouyanni K., Touloumi G., Samoli E., Gryparis A., Le Tertre A., Monopolis Y.Y. and Tossi G. (2001), Confounding and effect modifica modification in the short-term effects of ambient particles on total mortality: results from 29 European cities within the APHEA2 project, Epidemiology, 12, 521-531.

Katz S.A., Chatt A. (1998), Hair analysis in the biomedical and environmental sciences. New York: VCH Publishers.

Kelepertzis A.E. (2007), Geochemistry. Symmetria Eds., Athens, Greece.

Kunzli N., Kaiser R., Medina M., Studnika M., Chanel O., Filliger P., Herry M., Horak Jr. F., Puybonnieux-Texier V., Quenel P., Schneider J., Seethaler R., Vegnaud J.C. and Sommer H. (2000), Public-health impact of outdoor and traffic related air pollution: a European assessment, Lancet 356(9232), 795-801.

Laksmi Priya M.D. and Geetha A. (2010), Level of trace elements (copper, zinc, magnesium and selenium) and toxic elements (lead and mercury) in the hair and nail of children with autism, Biol Trace Elem Res, 142, 148-158.

Li X., Poon C. and Liu P.S. (2001), Heavy metal contamination of urban soil and street dusts in Hong Kong, Applied Geochemistry, 16, 1361-1368.

Liu B., Wu E., Li X., Fu Z., Deng Q., Mo C., Zhu J., Zhu Y. and Liao H. (2011), Arsenic, antimony and bismuth in human hair for potentially exposed individuals in the vicinity of antimony mines in Southwest China, Microchem J, 97, 20-4.

Ljung K., Otabbong E. and Selinus O. (2006), Natural and anthropogenic metal inputs in urban Uppsala, Sweden, Environmental Geochemistry and Health, 28, 353-364.

Manalis N., Grivas G., Protonotarios V., Moutsatsou A., Samara C. and Chaloulakou A. (2005), Toxic metal content of particulate matter (PM10), within the Greater Area of Athens, Chemosphere, 60, 557-566.

Mutter J., Naumann J., Scneider R., Walach H. and Haley B. (2005), Mercury and Autism: Accelerating evidence?, Neuroendocrinology Letters, 26(5), 439-446.

Nicolopoulou-Stamati P., Hens L. and Howard C.V. (2007), Congenital diseases and the environment, environmental science and technology library, vol 23. The Netherlands: Springer.
Nurnberg H.W., Valenta P., Nguyen V.D., Gödde M. and de Carvalho U. (1984), Studies on the deposition of acid and ecotoxic heavy metals with precipates from the atmosphere, Fresenius J. Anal. Chem., 317, 314.

O'Carroll R.E., Masterton G., Dougall N., Ebmeier K.P. and Goodwin G.M. (1995), The neuropsychiatric sequelae of mercury poisoning. The mad hatter's disease revisited, $\mathrm{Br} J$ Psychiatry, 167, 95-98.

Pope III C.A., Burnett R.T., Thun M.J., Cale E.E., Krewski D., Ito K. and Thurston G.D. (2002), Lung cancer, cardiopulmonary mortality and long-term exposure to fine particulate air pollution, Journal of American Medical Association, 287, 1132-1141.

Ramazzini B. (1983), Diseases of Workers. Birmingham, AL:Classics of Medicine Library.

Remoundaki E., Bourliva A., Kokkalis P., Mamouri R.E., Papayannis A., Grigoratos T., Samara C. and Tsezos M. (2011), PM10 composition during an intense Saharan dust transport event over Athens (Greece), Science of the Total Environment, 409, 4361-4372.

Rodrigues J.L., Batista B.L., Nunes J.A., Passos C.J.S. and Barbosa F. Jr. (2008), Evaluation of the use of human hair for biomonitoring the deficiency of essential and exposure to toxic elements, Science of the Total Environ, 405, 370-376.

Rozos E., Efstratiadis A., Nalbantis I. and Koustogiannis D. (2004), Calibration of a semi-distributed model for conjunctive simulation of surface and groundwater flows, Hydrol Sci-J-Sci Hydrol, 49.

Sawidis T., Krystallidis P., Veros D. and Chettri M. (2011), A study of air pollution with heavy metals in Athens city and Attica basin using evergreen trees as biological indicators, Biol Trace Elem Res., http://dx.doi.org/10.1007/s12011-012-9378-9.

Scheff P.A. and Valiozis C. (1990), Characterization and source identification of respirable particulate matter in Athens, Greece, Atmos. Environ., 24A, 203-211.

Schroeter J.D., Nong A., Yoon M., Taylor M.D., Dorman D.C., Andersen M.E. and Clewell H.J. 3rd (2011), Analysis of manganese tracer kinetics and target tissue dosimetry in monkeys and humans with multi-route physiologically based pharmacokinetic models, Toxicol Sci, 120, 481-498.

Schuhmacher M., Domingo J.L., Llobet J.M. and Corbella J. (1991), Lead in children's hair, as related to exposure in Tarragona province, Spain, Sci Total Environ, 104, 167-17.

Schuhmacher M., Bélles M., Rico A., Domingo J.L. and Corbella J. (1996), Impact of reduction of lead in gasoline on the blood and hair lead levels in the population of Tarragona Province, Spain, 1990-1995, Sci Total Environ, 184, 203-209.

Selevan S.G., Rice D.C., Hogan K.A., Euling S.Y., Pfahles-Hutchens A. and Bethel J. (2003), Blood lead concentrations and delayed puberty in girls, N. Engl. J. Med., 348, 1527-1536.

Sen J. and Chaudhuri A.B.D. (1996), Human hair lead and copper levels in three occupationally unexposed population groups in Calcutta, Bull Environ Contam Toxicol, 57, 321-326.

Srogi K. (2004), Heavy metals in human hair samples from Silesia province: influence of sex, age and smoking habit, Problems of Forensic Science, 60, 21-34.

Srogi K. (2006), Hair analysis - a tool in biomedical, environmental and forensic sciences: a review of literature published after 1989, Chem Anal (Warsaw), 51, 3-34.

Srogi K. (2006), Hair analysis for monitoring environmental pollution and the resulting human exposure to trace 
elements: An overview, Environnement, Risques \& Sante, 5, 391-405.

Taylor A. (1986), Usefulness of measurements of trace elements in hair, Ann Clin Biochem, 23, 364-378.

Thomaidis N.S., Bakeas E.B. and Siskos P.A. (2003), Characterization of lead, cadmium, arsenic and nickel particles in the Athens atmosphere, Greece, Chemosphere, 52, 959-966.

Torfs K. and van Grieken R. (1997), Chemical relations between atmospheric aerosols, deposition and stone decay layers on historic buildings at the Mediterranean coast, Atmos. Environ., 31, 2179-2192.

Vahter M. (1982), Assessment of human exposure to lead and cadmium through biological monitoring. UNEP/WHO, 7. Stockholm: GEMS; National Swedish Institute of Environmental Medicine and Department of Environmental Hygiene; Karolinska Institute.

Valente D., Cassini M., Pigliapochi M. and Vansetti G. (1981), Hair as the sample in assessing morphine and cocaine addiction [Letter], Clin Chem, 27, 1952-1953.

Vasilakos C., Pateraki S., Veros D., Maggos T., Michopoulos J., Saraga D. and Helmis C.G. (2005), Temporal determination of heavy metals in PM2,5 aerosols in a suburban site of Athens, Greece, J Atmos Chem, 57, 1-17, doi:10.1007/s10874-0069058-2.

Vassilakos C., Veros D. and Michopoulos J. (2007), Estimation of selected heavy metals and arsenic in PM10 aerosols in the ambient air of the Greater Athens Area, Greece, J. Hazard. Mater., 140, 389-398.

Wilhelm M., Lombeck I. and Ohnesorge F.K. (1994), Cadmium, copper, lead and zinc concentrations in hair and toenail of young children and family members: a follow-up study, Sci Total Environ, 35, 174-185.

Winneke G., Altmann L., Kramer U., Turfeld M., Behler R., Gutsmuths F.J. and Mangold M. (1994), Neurobehavioral and neurophysiological observations in six year old children with low lead levels in East and West Germany, Neurotoxicol, 15(3), 705-713. 